УАК 94(497.115)"186"(093.3)

061.23:929 Ирби А. П.

821.111.09-992 Ирби А. П.

doi: $10.5937 /$ bastina30-26781

Marko P. ATLAGIĆ*

Originalni naučni rad

Faculty of Philosophy in Kosovska Mitrovica

Aleksandar L. MARTINOVIĆ**

Faculty of Law in Novi Sad

Dalibor M. ELEZOVIĆ ${ }^{* * *}$

Faculty of Philosophy in Kosovska Mitrovica

\title{
NOBLE ENGLISH WOMAN ADELINE PAULINA IRBY ON KOSOVO AND METOHIJA IN SERBIA ${ }^{1}$
}

"One of the kindest persons among English people,
the one that was living and dying
for Serbian people - Miss Paulina Irby"

Ivo Andrić

\begin{abstract}
This paper is about Adeline Paulina Irby, an English lady. She left deep trace and indelible mark in memory of Serbs from Bosnia and Old Serbia (Kosovo and Metohija). Furthermore, it is focused on her journey through whole "European Turkey" (the Balkans) where she was acquainted with living conditions of the Christians there. She informed England and the whole western world about it. For that purpose, she travelled through Old Serbia-Kosovo and Metohija. Irby broke all the stereotypes Western World adhered to, in the first place stereotypes about "wild Slaves living in the Balkans". Irby presented to English reader the whole truth about Serbian nation whose Empire was conquered by Ottomans. Paper is particularly focused on her humanitarian work.
\end{abstract}

Key words: Paulina Irby, humanitarian, Ottomans, Serbs, travelling

Adeline Paulina Irby was born on 19 December 1833 in Boyland Hall near Morning Thorpe in England. Her father was Rear-Admiral Frederick Paul Irby and mother Frances Wright, daughter of a rich banker. Coming from an aristocratic family, Adeline was entitled to all aristocratic privileges for her entire life.

* Full Professor, atlagicmarko@gmail.com

** Associate Professor, a.martinovic101@gmail.com

*** Associate Professor, dalibor.elezovic@gmail.ac.rs

1 Adeline Paolina Irby-Mur Mackenzie, “Travels in the Slavonic Provinces of Turkey-in-Europe”, Mijatovic, C. Belgrade: State Printing House, 1868. Book was printed in England in 1887. 
Irby's father died when she was 12 years old, and her mother died when Adeline was 20. After death of her parents, Adeline moved to London and lived with her sister and brother-in-law. In London, she continued her education in Classic and English language courses, as well as arts.

As a person, Adeline was very independent and energetic, but also very curious at the same time. In London, she met Georgina Muir Mackenzie with whom she travelled through European provinces of Turkey later on. Thanks to noble Serbian historian Čedomilj Mijatović, she published a book "Travels in the Slavonic Provinces of Turkey-in-Europe”. The book is among the most valuable ones written by a foreigner. Just two years after it had been published in London, the book became available also in Belgrade, in the State printing house of the Principality of Serbia. The causes that led to emergence of this book were multiple - educational, pedagogical and political. Two travelers and missionaries from England linked their own curiosity with humanitarian work. They visited Christian peoples under Ottoman rule with an aim of providing readers in England with accurate and personal insight about unknown and inaccessible parts of "European Turkey", since information about those areas was not only very different, but also often inaccurate. ${ }^{2}$ This book contained 533 pages and became true sensation in Europe of that time. In the same year, book was republished in New York and caused great interests in other western countries as well. This book sent the truth about lives of South Slaves to the world.

The journey of those two young ladies through "impassable and wild parts of European Turkey" as Arthur Evans named it in the $19^{\text {th }}$ century, was a true accomplishment. ${ }^{3}$ Many historians wrote about Adeline Irby and her humanitarian work, especially during uprising in Bosnia and Herzegovina (1875-1878). Among them were: Sreta Milovanović ${ }^{4}$, M. Sv. Vulović, ${ }^{5}$ Arkadije Varabanin 6 , Julka Jonić ${ }^{7}$, Petar Mirković ${ }^{8}$, Jelena Lazarević ${ }^{9}$, Danica Kaća Čolović, Srđan

2 Slavica Garonja Radovanović, Travelogue about Kosovo and Metohija on the South Slavonic Countries in Austria and Turkey in Europe (1866) Miss Adeline Paolina Irby and Muir Mackenzie. In: Kosovo and Metohija in civilization circles, book 2, Kosovska Mitrovica: Faculty of Philosophy, 2010, pp. 231-243.

3 Arthur John Evans, Ilirska pisma = Illyrian lettres, London 1878 (Besjeda i Grafid ), Banja Luka 2008, p. 197.

4 Steva Miladinov, Miss Adeline Paolina Irby- Serbian humanitarian, Strazilovo (1886), pp. 1569-1574.

5 Sv. M. Vulovic, Miss Adeline Paolina Irby. In: Calendar for 1912, Belgrade-Serbian, 1911, pp. 123-125.

6 Arkadije Varadjanin, Miss Adeline Paolina Irby died, Yearbook of Matica srpska, 283 (1911), p. 78.

7 Julk aJonic, Miss Adeline Paolina Irby, Woman, 9 (1911), p.558

8 Mirkovic Petar, Miss Adeline Paolina Irby Serbian humanitarian, Sarajevo, Zemaljska štamparija, 1921.

9 Jelena Lazarevic, Englishwoman among Serbian people, Belgrade, Housewife - Belgrade female society, 1929. 
Čolović $^{10}$, Vasa Čubrilovićc ${ }^{11}$, Stanoje Stanojević ${ }^{12}$ and many others. In 1859, the two humanitarians visited Germany, Austria, Czech Republic, Poland and Hungary. They were travelling in horse drawn carriages and they were staying in roadside taverns. The main purpose was to meet and to get familiar with people and lands they were passing by. On their way across the Tatra Mountains, they were suspected by Austrian authorities of espionage and supporters of panSlavism, and spent one day in custody. However, that experience incited them to learn languages and history of Slavic nations. Upon their return to England, they anonymously published travel book entitled "Across the Carpathians". In 1862, they started their second journey through Europe. In Prague František Palacký, ${ }^{13}$ historian and politician, made them interested in history of Serbs and suggested them to visit Serbia and Montenegro. Through Vienna, Irby arrived to Trieste, then by ship to Corfu and Montenegro and finally to Athens and Bosporus. In the month of May, they obtained the Sultan's Fermanto travel throughout "European Turkey" and they started journey from Constantinople. At the beginning of August, Irby arrived in Niš through Edirne City. However, at the border crossing to the Principality of Serbia, authorities sent them to the city of Kragujevac, where Professor Josif Veselić was their designated guide. ${ }^{14}$

They visited monasteries Ravanica and Manasija, Archaeological site Gamzigrad, abundant villages and cities in Negotin area, Majdanpek, where Irby got especially interested in mining. After they had rested for five days in the City of Požarevac, they travelled on the Danube by ship and arrived in Belgrade. At the Port of Belgrade, they were welcomed by Franjo $\mathrm{Zah}^{15}$ and Nikola

10 Danica Kaca Colovic, Srdjan Colovic, Noble Miss Irby, humanitarian of Serbs, Belgrade, Serbian cultural society “Zora” pp. 205-211.

11 Vasa Cubrilovic, Bosnian uprising 1875-1878, Belgrade-Serbian Royal Academy, 1930

12 Stanoje Stanojevic, History of Serbian people in Middle Ages, Belgrade: Endowment of Kameniko and Pavle, Jovanovic Brothers, 1937, pp. 114-115.

13 František Palacký (1789-1876) Czech politician, historian, leader of Czech enlightenment in 19th century. He was the leader of Federal party and advocated Austrian federation. He graduated from protestant Gymnasium in Presburg (Bratislava), where he met Pavel Josif Safarik, philologist and slavist. After studies, he served as private teacher. He moved to Prague in 1813 and soon he became the editor of "Czech museum magazine"- the most important magazine written in Czech language. His major piece is "History of Czechs in Czech and Moldavia”. During 1848 Revolution, he entered politics and become President of First pan-Slavic congress in Prague. He also served as a member of Austrian Senate. He stood for Kingdom of Czechs that would include Czech, Moravia and Silesia.

14 Josif Veselić (1823-1873), philosopher and theologian. He supported Ljudevit Gaj and Illyrian movement. After he had moved to Serbia, he worked in the Court, in Serbian Telegraph and in Gymnasium in Kragujevac as professor of German, Greek and Latin language.

15 Franjo Zah, philosopher and theologian, solider and general-in-chief in Serbian army, active pan-slavist. He graduated in 1824 in Brno Gymnasium and in 1828 at the Faculty of Law in Vienna. He lived in France, where he studied Military science. He worked as Librarian and Translator in Frontenbl and translated Decart's "Tactics" from German into French language. 
Krstić. ${ }^{16}$ Krstić taught them Serbian language and informed them about circumstances in Serbia. After Belgrade, they visited Vojvodina and then Bosnia, since "Slavs under Ottoman rule" were of their particular interest. From Sarajevo, they travelled to Mostar and Dubrovnik.

In 1863, Irby visited Kosovo and Metohija. Few years later, notes from that trip were published as part of the famous travel book. In the period 1863-1864, Irby visited Belgrade for the second time. It is where she wrote a major part of her travel book "Travels in the Slavonic Provinces of Turkey-in-Europe". In Belgrade, she also translated the book "History of the Serb Nation" originally written by Nikola Krstić. In England, she established "The Fund for educating girls in Slavonic Provinces of Turkey-in-Europe“. In 1868, the State printing house published "Travels in the Slavonic Provinces of Turkey-in-Europe", co-authored by G. M. Mackenzie and A. P. Ibry. The book was translated into Serbian language by Čedomilj Mijatović. Together with Mackenzie, Ibry established a School for girls. The college had special aim - to empower young women to be teachers. Mackenzie got married meanwhile; hence, Irby took P. H. Johnson ${ }^{17}$ as an assistant.

After the outbreak of uprising in Bosnia and Herzegovina in 1875, Irby moved her students from Sarajevo to Vienna, to the higher school for girls. At that time, the Bosnian and Herzegovinian Fugitives Orphan Relief Fund was established in England. Irby personally provided help to Serbian refugees. She established in Pakrac and other parts of Slavonia 19 schools with around 1900 boys and girls refugees enrolled. She accommodated children in private houses and paid for their support. Each pupil was provided with free shoes, clothes, books and other supplementary school equipment and had one big bread for lunch. Twenty-two male and one female teacher worked in the schools. ${ }^{18}$ Primary school in Pakrac was placed in a beautiful house and accepted 100 Serbian children. Schools were opened also in Kukunjevac, Toranj, Jagma, Korita,

During his stay in Belgrade, where he served as attaché in French Consulate in Serbia, he provided help to Polish emigration. Ilija Grašanin was inspired by Franjo's "Plan for Slavic politics in Serbia". Based on that work, Grašanin wrote "Načertanije". Zach established Belgrade army school that later became Military Academy. On Prince Mihailo Obrenović's proposal, he became head of Military authority in Kragujevac. He received a military rank of general. He served as head of Serbian General Staff of Serbian Army, as well as commander-in-chief of Western-Morava division.

16 Nikola Krstić (1829-1902), Serbian historian, $\mathrm{PhD}$ in Laws, professor in Belgrade, member of Appeal Court, President of Main Cassation Court, state advisor. He was a member of "Društvo slovenske prismenosti" and "Srpsko učeno društvo".

17 P. H. Johnson was a granddaughter of famous Buxton whose contribution to emancipation of black and to the end of slavery in British colonies was enormous. Her brother and father were respectable members of English parliament.

18 Teachers were: Marija Mališić, T. Mališić, G. Kovačević, K. Kovačević, V. Kovačević, N. Parić, N. Selaković, N. Karanović, M. Bjelanović, M. Nikolić, Širo D. Gaković, S. Nedimović, G. Kondić, S. Prokopić, N. Školniki P. Mirković. 
Breznik, Rogulje, Novska, Paklenica, Rajić, Okučani, Medari, Nova Gradiška, Petrovo Selo, Benkovac and Galešina. ${ }^{19}$ In 1876, a two-day course was organized for them in Pakrac Preparatory school. After the outburst of war between Serbs and Turks, Serbs were pressured all over Slavonia and some of them were even detained. Moreover, in 1874 all the schools were closed, the only exception was Pakrac, and Adeline Irby was expelled. In 1877, the Austrian authorities forbade Dimitrije Josić, ${ }^{20}$ who was a supervisor of Irby's schools, to continue with his duties. ${ }^{21}$ However, together with six teachers she moved her humanitarian work to Dalmatia, where she established four schools (in Knin, Plavna and other places) and one orphanage. In monastery Krka, a monument dedicated to her was placed among monuments to other noble persons that helped Serbs in Dalmatia. Some of them helped by written words, some by sword, some by humanitarian work - King Petar I Karađorđević, Dositej Obradović, Vuk Stefanović Karadžić and Adeline Paulina Irby. ${ }^{22}$ In 1992, Serbs dedicated another monument to Irby in Strumica and Plavno, not far away from Knin. However, all of them were completely destroyed after the criminal operation "Storm", conveyed by Croatian military. Thus, they shared the same destiny as the monument from the Krka monastery. ${ }^{23}$ In 1879 , Paulina returned to Sarajevo and refurbished the school and student dormitory. The School for girls was expanded and the School for boys was established.

The majority of the travel book was dedicated to the journey through Kosovo and Metohija and the chapter was named "Entering Serbian lands", i.e. Raška, Kosovo and Metohija- Old Serbia.

When Irby arrived in Kačanik, the local citizens introduced her to details of that region. She was informed that Sultan Murad or "Turkish Emperor Murad" passed through Kačanik when he led his army to Kosovo Polje in 1389. Albanians live in Kačanik and Austrians loved them because Albanians fought against Bulgarians and Serbs. Furthermore, Irby was told that Kosovo Polje was well inhabited before the Turks came. Even Serbian trade fairs were organized there. There were fairs held in neighboring cities Skoplje, Prizren and Novo Brdo where foreign merchants were gathering. Irby was told that Kosovo Polje had been a battlefield for centuries. The first battle took place in the $12^{\text {th }}$ century between Stefan Nemanja and governor of Zvečan. After that battle, the Serbs of that region were liberated and Byzantine Suzerainty came to an end. The locals also told Irby about the battle in 1448, when Hunyadi János (Serbian: Sibinjanin Janko), Hungarian commander-in-chief, fought against the Turks.

19 Mirkovic Petar, Miss Adeline Paolina Irby, 1921, pp. 3-17.

20 Dimitrije Josić left Croatia and moved to Serbia, where he worked as professor in School for teachers and at the Faculty for theology for two decades in Belgrade.

21 Evans, Ilirska pisma, p.161.

22 Milan, Četnik, Art anniversary in Krka monastery, Politika 21/08/2011, p. 1.

23 Colovic, Colovic, Noble Miss Irby, p. 9. 
He was led by great hope to conquer the country. Furthermore, Irby learnt about the battle on Vidovdan, held on 15 June 1389, when the Turkish army, led by Murad I, attacked the Serbs. In that battle, Sultan Murad and Serbian Prince Lazar Hrebeljanović lost their lives. There are three versions of the account of the battle. According to the first, the Serbs beat the Turks on Kosovo Polje, according the second the Turks won and according the third version, it ended up as neutral.

From Kosovo Polje, Irby went to Gračanica, where she visited Monastery Salvation. Alongside other biographies, there is a fresco of King Milutin (1282-1316), a founder of the Monastery, and his wife Simonida, daughter of Byzantine Emperor Andronikos II Palaiologos. Irby learnt that King Milutin founded more than 48 monasteries and churches. Among the frescos, there is a preserved fresco of Christ's head, the height of a pilaster.

When Irby arrived in Priština, she visited one Christian school. A teacher in the school was from Sremska Mitrovica. Children had books from Belgrade. The books were written in Cyrillic letter. Irby heard from the teacher that children were not allowed to use Serbian books in public. Turkish officers often visited and controlled the school.

From Priština, Irby went to Vučitrn. She stayed with a hospitable Orthodox priest Denča and his wife. Apart from the Serbian school with the young teacher and 16 pupils, she also visited Albanian school. Irby noticed that girls learnt Turkish prayers by heart, even though they did not know how to read and write. The person Irby was accompanied by warned her that their visit might cause troubles because Vučitrn is not Constantinopolis but "Arnavudluk" and "Giaours" are considered infidels. A group of young scroungers attacked her throwing stones, so she experienced it by herself. After Irby's protector Albanian was hit by a stone, he grabbed a "khan jar" (knife) and chased the attackers away.

Monks respectfully welcomed Irby to the Patriarchate of Peć. After she had been acquainted with the Patriachate, she was told that the Catholics made more damage than good to the Christian cause, ${ }^{24}$ because they often took part in actions against other Christians and took care just about their personal benefits.

In Peć she learnt about longing of the Serbs for education and for keeping memories about the education in past, as well as their wish to establish schools. Every school book as well as each teacher came from free Serbia. She described especially how Serbian girls from Peć were beautiful. Irby wrote about one of them: "True beauty, both in face and her attire. Her pliable silhouette was a bit taller than average, round like in classical statues, facial lines were so gentle, and face was so white and rosy, that we could not help but suspect in that blackness of the eyebrow and hair the artificial imposition of colour. She wore ducats

24 Irby-Mackenzie, Traveling through Slavic countries of, p.290. 
and pearls on red string around her neck and head". ${ }^{25}$ They had seen nowhere such a beauty, volubility, freshness and constitution. Irby said: "We have not seen anywhere in the area women, after their first youth, so agile and fresh with such a beautiful body constitution, and such a beautiful expression as Serbian women from Peć have" ${ }^{26}$ She was interested in handicraft, admiring the beauty of the national costumes, she even bought some parts of traditional clothes, packed them and brought with herself. In their book, Miss Irby and Miss Mackenzie examined the status of women at the Balkans in the first part of the $19^{\text {th }}$ century. Furthermore, Irby met the Catholic Arnauts. She wanted to meet Katarina Simić, teacher from Belgrade who served as a nun and teacher in Peć. Katarina was among "the most notable persons whom they met in Turkey and one of the most honest and reputable women they had met at all". ${ }^{27}$ In Peć, on the recommendation of the city governor, they visited Arnaut, Latin and two Serbian schools. In Serbian school for boys, room was small but full of pupils who welcomed them with song. Schoolbooks they used were from Belgrade. Pupils and teachers complained that they had not had maps. Irby also visited school for girls, the one led by teacher Katarina. That school was even more modest as Arnauts could not stand luxury. The school had 27 girls who could read and write Serbian and Old Slavonic language. The school had no books, hence Irby gifted some.

In Peć, they visited the Latin Church - small but new. Books were from Rome, while prayers in them were printed in two languages - at one page it was in Latin, while on another page it was in Arbanasi. They learnt from the priest that Peć contained just 15 to 20 Catholic households, while the whole parish consisted of 100 to 200 Catholic houses. The priest also told them that Turks behaved much better in relation to the Catholics than to the Serbs. Irby found out that the Serbs were suffering so much that no language could describe: "our life and our property, our women and our children can't put up with it; they hang on mercy of one group of criminals. Our governors, our judges and police, all of them are thieves, bloodsucking criminals. ${ }^{28}$

When you come to Prizren, every step tells you about Arbanasi present and Serbian past. ${ }^{29}$ Minaret on the main Mosque is made of wood and it looks like pepperbox, but in base, it was a wide tower made of stone. Behind the tower, there were five pilasters of a church. Doors of another mosque are made of pillars taken from a monastery nearby. Trace of cross remains visible in the stone. Irby visited palace of Catholic bishop in Prizren. She did not meet the bishop

25 Ibid, p. 298.

26 Ibid.

27 Ibid, p. 292.

28 Ibid, p. 303.

29 Ibid, p. 333. 
as the last one had died and a new one did not arrive. While she was in Prizren, she visited St. Đurađ Church built by Stefan Nemanja. Alongside schools, monasteries and temples, she visited houses where ordinary people lived. She described one of Albanian houses as following: "Their house was placed at the foothill. Divided into two parts, the so-called 'house' was intended for kitchen, children, women and the tower with holes. Purpose of the holes was to sustain protection against potential incoming enemies - the main aim was to shoot through them" ${ }^{30}$

Irby described national traditional clothing. She noted that governor's wife and daughter would welcome her "dressed up embellished with jewelry, shirts made of white linen and silk, beautifully and abundantly weaved with gold“" ${ }^{31}$ She liked the clothes that women from Bosnia and Montenegro wore. For Montenegrins she noted: "majority of wealth they possess, they wear on themselves, shiny embellished arms, silver belt buckles and sable“. ${ }^{32}$ She described Prizren as the Serbian Constantinople and as a place where Serbian assemblies convened. She pointed out that Prizren is a place for merchants, where the Serbs and the Bulgarians exchanged their products for different goods coming from the West. She learnt that there were 350 Orthodox churches and monasteries near Prizren. She also learnt that the last Serbian emperor moved the Serbian capital from Prizren to Kruševac before the Kosovo battle in 1389. During four centuries of Ottoman rule, the Turks destroyed all architectural Serbian decorations. In that time, Prizren had 46,000 inhabitants - 32,000 Muslims, 12,000 Orthodox Christians and 2000 Catholic Christians.

\section{SOURCES AND LITERATURE}

Макензијева и Ирбијева 1968: ААелина Паолина Ирби и Мјур Макензијева. Путовање по славенским земьама Турске у Европи. БеограА.

Радовановић 2010: Славица Гароња Радовановић, Путопис о Косову и Метохији по славенским земљама Турске у Европи (1866) Мис ААелине Паолине Ирби и Мјур Макензи, у: Косово и Метохија у цивилизацијским токовима, књ. 2. Косовска Митровица. Филозофски факултет.

Еванс Бања Аука 2008: Артур Јохн Еванс. ИАирска писма= Illirion lettres. Бања Аука (фототипско издање).

Миловановић 1866: Стева Миловановић. Мис Аделина Паолина Ирби српска добротворка. Стражилово, бр. 45. Нови СаА.

Вуловић 1911: М. Св Вуловић. Мис Аделона Павлиоја Ирби. Српска црква. БеограА

Варабонин 1911: Аркадије Варабонин. Умрла је Мис Аделина П. Ирби, Аетопис Матице српске. Нови СаА.

$30 \quad$ Ibid, p. 382.

31 Ibid, p. 348.

32 Ibid, p. 455. 
Јонић 1011: Јанко Јонић. Мис ААекина Ирби. Жена, бр. 9. Београд.

Мирковић 1911: Петар Мирковић, Мис Адекина Павлија Ирби. Сарајево.

Аазаревић 1919: Јемена Аазаревић, Енглескиња у српском народу. БеограА.

Чочовић 2004: Ааница Кача Ћоловић. Племенита Мис Ирби добротворка српског народа. Зора. БеограА.

Чубриловић 1930: Васа Чубримовић. Босански устанак 1875-1878. БеограА.

Станојевић 1937: Станоје Станојевић, Историја српског народа у средњем веку. БеограА. Четник 2011: Мияан Четник. Уметнички јубилеј у манастиру Крки. Политика. БеограА.

Гиьфердинг 1996: Александар Гиљфердинг. Путовање по Херцеговини, Босни и Старој Србији. (превео ЗАенко Шкунарица). БеограА.

Поповић 1976: Миодраг Поповић. ВиАовАан и часни крст. Слово ьубве. БеограА. 


\author{
Марко П. АТААГИЋ \\ Александар $\Lambda$. МАРТИНОВИТ \\ Аалибор М. ЕАЕЗОВИТ
}

\title{
ПАЕМЕНИТА ЕНГАЕСКИЮА ААЕАИНА ПАУАИНА ИРБИ НА КОСОВУ И МЕТОХИЈИ У СРБИЈИ
}

\begin{abstract}
РеЗиме
У раду се говори о пиеменитој Аделини Паолини Ирби, која је зајеАно са Георгином Мјур Макензи, пропутовала „европску Турску“, како би се упознала са стварним животом хришћана у њој и о томе тачно известила западну јавност. У ту схрху, пореА осталих, пропутовала је кроз Босну и Херцеговину и Стару Србију-Косово и Метохију. Са оАличним познавањем историје и традиције, у преплету са реалним околностима, живели су Срби поА отоманском вмашћу и албанским притисцима. Ирби је вршила добротворне активности, те је пореА осталог, отворияа много српских шкома у Босни и Херцеговини, Косову и Метохији, али и деветнаест школа у Славонији и неколико у Ааммацији. Ирби су интересовале европске области под турском вцасти (Аанашњи Балкан) и стање словенског становништва, који је живео у веома тешким условима. Путовала је са коњским запрегама, понекаА и на коњима, праћена наоружаним чуварима. Обишла је Бугарску, Босну, Србију са Јужном Србијом (Косовом и Метохијом), Македонију и Албанију. Своје утиске објавима је у путопису „Путовање по славенским земьама Турске у Европи“, коју је објавила у Аондону 1867. године. Упознала се са изузетно мошим условима у којима је живео српски нароА поА турском влашћу. Несреће српског народа које је видема пробудиле су у њој осећај милосрђа, те је одлучима Аа се посвети раду, на помоћи српском народу. Посебно ју је погодила тешка ситуација Срба на Косову и Метохији обиказећи Качаник, Призрен, Пећ, Косовску Митровицу, Косово Пове и Аруга места. Видела је многе српске православне манастире, Грачаницу, Пећку патријаршију... Тешко је наћи у историји српског народа таквог Аобротвора каква је бима Ирби, тим више што је бима странац.
\end{abstract}

Key words: Паолина Ирби, хуманитарка, Отоманско царство, срби, путовање.

РаА је преАат 23. маја 2020. године, а након мишьења рецензената, оАлуком оАговорног

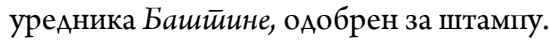

